Diasporic Visions: Colonialism, Nostalgia and the Empire in Gurinder Chadha's Viceroy's House

Dr Clelia Clini

Institute of Media and Creative Industries, Loughborough University London, London, UK

ORCID: https://orcid.org/0000-0003-0841-9714

Scopus: https://www.scopus.com/authid/detail.uri?authorId=56465901400

Contact email: C.Clini@lboro.ac.uk

\title{
Abstract
}

Released on the $70^{\text {th }}$ anniversary of Partition, Gurinder Chadha's film Viceroy's House (2017), which is narratively and stylistically constructed in the fashion of heritage cinema, chronicles the last days of the empire in India and is said to provide a "British Asian perspective" on Partition. This article addresses the debate that followed the release of the film and, in particular, the analysis focuses on the interplay between Partition, diaspora, and representations of the imperial past. Through the analysis of the film's structure and narrative, the article discusses its representation of British India and argues that, notwithstanding its potential to unsettle traditional representations of the empire of period dramas, the film's glamorous depiction of the British rulers ultimately feeds into the contemporary wave of colonial nostalgia (Davis 2018).

Keywords: Indian diaspora, Partition, colonialism, empire, nostalgia, heritage cinema, imperialist fantasies. 


\section{Diasporic Visions: Colonialism, Nostalgia and the Empire in Gurinder Chadha's Viceroy's House}

'British' most of us were, at one time, but that was long ago and, besides, as Shakespeare said, 'the wench is dead. 'English' we cannot be (Hall 1999, 13)

\section{Introduction}

In March 2017, as India celebrated seventy years of independence from British colonial rule, Gurinder Chadha released Viceroy's House, a film that dramatizes the final days of the empire and which narrates the events that led to, and followed, the independence of British India and the Partition between India and Pakistan. Described by the filmmaker as her own "upstairs and downstairs film in the tradition of Downton Abbey and Gosford Park" (2016), Viceroy's House opens with the arrival of the last viceroy of India Lord Mountbatten, and his family, to Delhi and it chronicles the unfolding of the events that led to Partition. By interweaving the stories of the Mountbattens and their entourage (upstairs), and those of the servants (downstairs) the film dramatizes the negotiations taking place between British colonial authorities and the Indian political leaders over the transfer of power while portraying the consequences of these same negotiations on the Indian servants who are employed in the house. The film emphasises in particular the disruptive effects of the upcoming division of the country on the otherwise harmonious community constituted by the employees of the Viceroy's residence. Among them are Aalia and Jeet, two star-crossed lovers whose relationship challenges the ever rigid religious endogamy in the run up to Partition - as Aalia is a Muslim while Jeet is a Hindu. The scale of the tragedy on the Indian (and soon to be Pakistani) people is conveyed through the insertion into the narrative of Movietone 
newsreels, which chronicle the growing communal violence taking place around the country, and remind the audience that the film is based on true events.

With an estimate of nearly two million people killed during the riots that accompanied independence and some fifteen million people uprooted (Darlymple, 2015; Mishra, 2002, 211), Partition remains, in the words of Bhaskar Sarkar "a festering wound in the collective psyche of South Asia" $(2009,1)$. It is therefore not surprising that, upon its release, Viceroy's House triggered a heated public debate over its representation of the events. In an article published in The Guardian on the very day of its release (3 March 2017), Fatima Bhutto defined Viceroy's House as a "film of a deeply colonised imagination" and wrote that it was a "servile pantomime", also accusing Chadha to blame Partition entirely on Muslims and Jinnah (Bhutto, 2017). In response to Bhutto's article, journalist and writer Sufiya Ahmed, a few days later, retorted from the pages of the Huffington Post that Bhutto's allegations were a consequence of her inability, as a member of the Pakistani elite, to "get the Brit Asian experience" (2017). She especially took issue with Bhutto's statement about the film reproducing a "colonised imagination" - a claim that, Ahmed wrote, was especially insulting for a child of immigrants "who lived through the extreme racism of the 60 and 70s" and was ultimately an attack on all "Brit Asians" (Ahmed, 2017). Indeed, Chadha herself had described Viceroy's House as her own "British Asian perspective on Partition" (Chadha, 2017a) and in several interviews given before and after the release of the film, the filmmaker explained that this is, for her, a very personal film, as it was inspired by the sufferings of her own family at the time of Partition.

This article is concerned precisely with the British Asian point of view that Chadha advocates for her film. By analysing its style and narrative structure, the article discusses the interplay between Partition, diaspora, and the representation of the imperial past. The nature of a diasporic perspective on Partition is explored by discussing the ways 
in which Viceroy's House frames colonial India, both visually and narratively, and how it re-constructs the relationship between and within colonised and colonisers. After an introduction on Partition and its legacy in present-day Britain, the film is contextualised within the socio-cultural context of an increasingly melancholic postcolonial Britain (Gilroy, 2004) and it is framed within the tradition of heritage cinema. The second part of the article engages in the analysis of the film's narrative and discusses the film's potential to subvert the ideology embedded in heritage cinema and to "rewrite the margins into the centre" (Hall, 1999, 10). Finally, the article will close with a reflection on Chadha's approach to heritage cinema in relation to her own diasporic position, questioning what it is that makes Viceroy's House a British Asian film.

\section{Partition, historical memory and the diasporic subjects}

As the "underside of independence" (Sarkar, 2009,1), the 1947 Partition of British India led to the creation of a new geography of South Asia, with newly drawn borders which, cutting across entire regions (particularly affected were Bengal and Punjab) demarcated the territories of the two sovereign states of India and Pakistan. The decision to partition the country in two, creating a new state (Pakistan) for the Muslim minority, was reached after months and months of consultations between the Indian political leaders and the British colonisers, a time during which the relationship between the two main parties which had spent years fighting side by side for independence went deteriorating, as did inter-communal relations within the country (see Khan, 2017). The period of transition between plans for independence and Partition saw the unleash of unprecedented violence between religious communities, and, on the official publication of the physical boundaries between India and Pakistan (not made public until two days after the British had officially left, on $17^{\text {th }}$ August 1947) millions of people crossed these new borders seeking refuge from communal violence. 
The scale of the violence was such that now the word Partition is often used metonymically to refer to the communal violence that accompanied independence. With violence came trauma, and, for decades after 1947, a deafening silence fell on this tragedy, both officially and unofficially (Butalia, 1998, 9; Mishra, 2012, 211). Official narratives of nationalism, rather than addressing Partition violence, focused on the struggle for independence and downplayed it as an exception, "an illegitimate outbreak of violence $[\ldots]$ against the fundamentals of Indian (or Pakistani) tradition and history" (Pandey, 2001, 3). The difficulty of making sense of the events was reflected also in the inability of survivors to find a language that would allow them to describe, and make sense of, such violence, an idiom that would allow to speak the unspeakable (Butalia, 1998, 2005; Das and Nandy, 1985; Nandy, 1999). This is the reason why Partition has been mostly theoretically analysed in terms of trauma, loss, mourning and melancholia (Butalia, 1998; Mishra, 2002; Nandy, 1999; Sarkar, 2009; Sengupta, 2015). According to Mishra, for example, the downplay of the violence of Partition as an aberration, an exceptional, temporary period of madness, prevented the nation - and its citizens - from the possibility of mourning:

This occluded history of India is the unspeakable canker that is silenced through what Don Miller has referred to as the economy of melancholia. If mourning became Electra because she knew what an 'uncompleted' mourning was like, then it is melancholia that becomes the India because we tend to carry our loss, unresolved, as painful splinter in our side. It is there for all to see, but we have never confronted it $(2002,211)$.

As such, the legacy of Partition extends to the present day (Butalia, 2005; Sarkar, 2009; Sengupta, 2015) casting its long shadow on the lives of those whose families have lived through it - both in the Subcontinent and the diaspora. The relevance of the legacy of 
Partition in the diasporic context is clear if we think of the significant role that memories and narratives of the past play in the formation of diasporic identities. Diasporic communities, as explained by Avtar Brah, are complex formations whose identities emerge at the intersection between present-day experiences, memories and re-memories of the past and real or imagined homelands $(1996,181-198)$. For diasporic subjects the past, Stuart Hall argued, "is always constructed through memory, fantasy, narrative and myth" $(1990,226)$ and if, as he maintains, "identities are the names we give to the different ways we are positioned by, and position ourselves within, the narratives of the past" $(1990,225)$, then we see the relevance of memories, and narratives, of Partition in the diasporic context.

Gurinder Chadha, a "self-identified Punjabi", born in Kenya and raised in London (Desai 2004, 130) admittedly "grew up in the shadow of Partition" (Viceroy's House Press Kit 2017, 1), as her family was directly affected by it: forced to flee their home in what was deemed to be Pakistan, they had to relocate to India - one of her aunties starving to death along the way (Chadha, 2016). The legacy of Partition, according to the filmmaker, are still of "huge importance" in Britain, and yet she feels that "the events of 1947 are largely forgotten in the UK" (Chadha, 2017b). This film represents thus for Chadha the means to bring attention to such a pivotal moment in South Asian (and British) history and to address all the parties involved in Partition with the stated aim of offering "a message of reconciliation" that would speak to Indians, Pakistanis and British people alike (Viceroy's House Press Kit, 2017).

\section{Viceroy's House, heritage and melancholic Britain}

Writing about the revival of the British Raj on screen in 1984, Salman Rushdie drew a connection between the popularity of narratives of "Raj revisionism" and the social and economic decline of the country at the time, arguing that Thatcherite Britain 
encouraged people to "turn their eyes nostalgically to the lost hour of their precedence" ([1984], 1992, 92). In light of his comment, the context within which Viceroy's House was made deserves some reflection. The film was released in Britain not only on the seventieth anniversary of Partition, but also during a period of growing (post)colonial nostalgia in British public culture. The 2010s in fact have seen the emergence of a number of films, TV series, popular music videos which offered a glamorous look at the "exotic" former colony of India ${ }^{1}$ (Andrews, 2016; Jeffries, 2015; Kumar, 2016). This nostalgic wave also encompasses British politics and influenced the public debate over the British membership of the European Union: in this respect Alexander Davis noted that, in the lead-up to the Brexit referendum, colonial nostalgia became the dominant force in British foreign politics" (Davis, 2018, 162). New dreams of a "Global Britain" project (also known as Empire 2.0) identified former colonial possessions, India in particular, as central for a post-EU British economy, offering a romanticised view of the empire completely whitewashed of its violence, one in which former colonies are described not as imperial possessions but rather as "old friends" (Davis 2018, $154-155$; see also Beaumont, 2017 and Law, 2019).

If, as Baena and Bekyr suggest, "nostalgia is less about the past than it is about the present" $(2015,261)$, this wave of colonial nostalgia in British cultural and political life can be read as a response to the challenges faced by contemporary society, undergoing an identity crisis after years of austerity and growing inequalities, combined though with the unresolved issue of coming to terms with the demise of the Empire and "to deal with its legacy" (Gardner, 2017, 10). The inability of Britain to process the end of the empire has been thoroughly analysed by Paul Gilroy, who remarkably observed that Britain's continuous re-visitations of its imperial past is the melancholic reaction "to the loss to a fantasy of omnipotence", i.e. the loss of the Empire $(2004,99)$. In an interview given to The Guardian in 2015 regarding the "recycled Raj fantasy", Gilroy observed that: 
The idea of the empire gets (re)visited obsessively because its loss remains painful but it cannot be worked through. Britain might learn too many uncomfortable truths about its history if it was known and considered. In the absence of that encounter, phenomena such as the Raj get recycled as fantasy. The lost greatness of the imperial period can thereby be fleetingly restored (Gilroy in Jeffries, 2015).

The renewed popularity of colonial India in popular culture thus appears related to unmourned loss of the Empire. As a film modelled on the tradition of period dramas such as A Passage to India (David Lean, 1984) and Gandhi (Richard Attenborough, 1982), Viceroy's House appears to fit in well within this wave of (post)colonial nostalgia. And yet, the very subjectivity of the filmmaker, as a British Asian woman, has the potential to add layers of meaning to the narrative that complicate melancholic fantasies of the empire.

Discussing the influence, in terms of style and concept, of period dramas such as Gosford Park and Downton Abbey on Viceroy's House, Chadha explained:

I love those huge, epic-canvas British films. I think it's sad that we don't make those kind of epic, populist films as much because they somehow help define who we are as a nation. They tell us who we are by going back, looking at our history to understand our present. That is exactly what I wanted to achieve here, to reach out to the broadest audience possible and remind them of this hugely important event that has been largely forgotten. (Viceroy's House press kit, 2017)

Chadha thus aims to use the format of period dramas to make people reflect on Partition and its legacy. Importantly, Partition is here intended as part of a shared forgotten British Asian history. Chadha's remark about heritage dramas defining the identity of the nation is quite interesting because, as much as heritage films do construct an image of the nation, this image is very selective and tends to project an exclusionary national identity.

The visual grammar of heritage cinema, Andrew Higson explains, is aimed at reproducing "imperialist fantasies of national identity", which emerge as a "conservative response to a collective post-imperial anxiety" $(2006,104)$. Heritage films on the British Raj, such as A Passage to India, Jewel in the Crown, Heat and Dust, invariably display a 
longing for a stable, idealised past in which the British Empire was still flourishing, and the social structure of society was neatly defined and unquestioned. Even when these films "chronicle the corrupt and last days of imperialist power, a period when that power was already coming under attack", they still display a nostalgic tone for a social order which is no more (Higson, 2006, 104).

This appears to be in contrast with the contemporary diverse character of British postcolonial society, to which Chadha belongs and to which she has been giving voice since the beginning of her career - so much so that, after the success of Bend it Like Beckham she earned 'the title 'queen of the multi' (which can ambiguously mean both multiplex and multiculturalism)" (Desai, 2004, 65). And yet, if the diasporic presence in Britain functions as a constant reminder of the imperial past, in a sort of, "we are here because you were there", as Kobena Mercer suggests $(1994,7)$, then Chadha's film might potentially adopt the period drama formula to subvert its logic, and to expose the human cost of British politics in the subcontinent. Indeed, following Stuart Hall, Chadha's adoption of the heritage film style could finally "rewrite the margins into the centre [...] representing more adequately the degree to which 'their' history entails and has always implicated 'us' across the centuries and vice versa" $(1999,10)$.

\section{Colonial Relations at the end of the empire}

The opening scene of the film strongly recalls the style of Downton Abbey's opening credits, as it offers a panoramic view of the magnificent mansion of the viceroy, where an impressive number of Indian servants (hundreds, we are told) are fretting about to get the house ready for the arrival of the Mountbattens. The emphasis on sumptuous mansions and the careful recreation of costumes and locations is a staple element of heritage films (Byrne, 2014, 312), where it is used to emphasise the splendour of the lifestyle of the upper classes but also the greatness of the lost Empire (Higson, 2006, 97, 
104). This is a sentiment distinctly voiced by Jeet Kumar, the newly appointed valet of the viceroy, who, upon entering the residence, contemplates it in awe and comments that this was exactly what he "imagined England to look like".

The characterisation of the Mountbattens closely recalls that of the ruling family of Downton, in turn deeply indebted to the heritage films of the 1980s (Byrne, 2014, 325). It is no coincidence that the viceroy is played by the same actor who plays the Earl of Grantham in the ITV series, Hugh Bonneville. Just like the Earl of Grantham, the viceroy is a liberal, just figure, who is conscious of his class and status but demonstrates a paternalist benevolence in his relationship with his servants (Byrne, 2014, 319). Mountbatten's wife Edwina and his daughter Pamela, for example, repeatedly define the task ahead of the viceroy in terms of "bringing freedom to India" - with no afterthoughts about the irony of the statement. The Mountbattens also display genuine concern about the political fate of the soon-to be independent country and Mountbatten's love for India is remarked upon a few times in the film, both by his friend Nehru and by Cyril Radcliffe, the lawyer who is appointed the task of drawing the borders between India and Pakistan. Despite being the cousin of the king - Aalia's father sharply points out that he has "Empire in his blood" - the viceroy seems not to be acquainted with the policies, and politics, of the empire: his shock at learning that Partition had all been settled by Churchill two years prior to his appointment - Chadha follows the events as narrated in Narendra Singh Sarila's book, The Shadow of the Great Game (2006) - reveals his naïve faith in what he regards as a "just" empire. Indeed, when he expresses his shock at learning that India was divided for oil makes one wonder whether he ever knew what colonialism was all about.

In this the film complies again with style of heritage films, which, Higson observes, "seemed to articulate a nostalgic and conservative celebration of the values and lifestyle of the privileged classes, [...] in doing so an England that no longer existed 
seemed to be have been reinvented as something fondly remembered and desirable" (2003, 12). In this case, England is metonymically the empire as understood by Mountbatten, this paternalist institution looking after its subjects, which is very far from the reality of colonialism. And yet, if the film is so much indebted to heritage cinema, it is crucial to note that, despite its association with "a nostalgic modern English upperclass" (Desai, 2004, 59) heritage films can also be highly ambivalent and subversive, potentially challenging the very system that they seem to uphold (Dave, 2006; Monk, 1995). Despite the characterisations of the Mountbattens as the well-meaning colonisers, Viceroy's House also shows a more brutal aspect of the empire. As a counterpart to the viceroy, the British officials who should overlook the transfer of power are not as thoughtful regarding Indians or the fate of India. General Ismay in particular is portrayed as the brutal face of the Empire: he is not concerned about the human cost of Partition, but rather wants to leave the country as soon as possible and make the most of it by dividing the country in two and securing British access to the Arab Sea via Pakistan . In line with the culture of the empire, he also adopts zoological tropes to describe the Indians (who are "as slippery as eels") a discursive device to strip colonised subjects of their humanity so to justify colonialism.

Other references to the violence of the British Empire are made throughout the film: both Nehru and Aalia's father (the late Om Puri) had been jailed for supporting independence, while references are made to the Jallianwala massacre, where Jeet's father was killed. And yet, these references, which have the potential to subvert the characterisation of the colonisers, remain somehow at the margins of the narrative as they are placed in the past, a place remarkably different from the viceroy's house. In the film, the residence appears like a peaceful island amidst, we are told, the chaos that is pervading the rest of India, which is visible through the Movietone newsreels. The violence of the 
colonisers remains firmly out of the house, and so does the violence between communities, except for a few skirmishes between servants.

Occupied by the Mountbattens, the viceroy's residence is a safe haven amidst the chaos that is descending on the rest of the country. The goodwill of the Mountbattens is reiterated when they offer their staff the opportunity to bring their relatives at the residence, so to save them from the atrocities which are taking place in the rest of the country. Such a division of space, the threatening outside world inhabited by Indians, juxtaposed to the safety of the house magnanimously opened by the viceroy, resonates uncannily with colonial narratives which, as Pramod Nayar noted, drew a "clear binary" between "the innocent, heroic, and stoic Englishman versus the barbarous and unfair Indian" $(2012,77)$. Even if the film blames Partition on the British government, it still seems to reproduce the colonial discourse of difference according to which, as Nayar again observed: "the English man or woman, no matter what the provocation, retains his or her civil behaviour" and keeps stressing "the benevolence of the English "conqueror"” $(2012,28)$.

The benevolence of the Mountbattens is nevertheless met with ambivalence by his Indian counterparts, the political leaders. Mountbatten treats them with the same paternalism with which he treats his staff, scolding them like children who are misbehaving when they are unable to agree on the future of India- "how can we leave he tells Nehru - when you can't agree on what your future should be?" And yet, they are the ones who remind him of the shortcomings of his beloved empire. Nehru provides Mountbatten with some home truths regarding British imperialist politics: as a response to the Viceroy's reprimands for their inability to reach an agreement, he reminds him that they "have done everything to foster hatred between their different communities: separate schools, elections, that was always your policy: divide and rule" adding: "now you have divided us, you ask me for a solution?" 
His observation is an important reminder of the devastating effect of colonial rule on the social texture of India, where the imported politics of group representation had the effect of creating a majority-minority dialectic which turned "indigenous ideas of difference [...] into a deadly politics of community" (Appadurai, 1996, 135). As Appadurai observes:

The process by which separate Hindu and Muslim identities were constructed at a macro level and transformed not just into imagined communities but also into enumerated communities is only the most visible pathology of the transfer of the politics of numerical representation to a society in which representation and group identity had no special numerical relationship to the polity (132).

And yet, this point is not explored further in the film. In a previous meeting with the cabinet, one official bemoans the fact that "this hatred between Hindus, Sikhs and Muslims" was "poisoning everything the British had built", rather than being the product of their very politics. When the prospect of Partition begins to acquire substance and the echo of disorders reaches the viceroy's residence, no reference to British imperial politics is made. Instead, the focus is on the first skirmishes between members of staff. No explanation is offered as to why people are fighting: it all seems to explode out of the blue, especially considering Jeet's remark that in his village, just like in many others, Hindus, Sikhs and Muslims have been living together like brothers for centuries ${ }^{2}$. What is problematic about the representation of communal violence is that it is treated matterof-factly and is not historicised, as Nehru's comment would have wanted.

As Partition looms, the staff of the viceroy begins to unrest and a feeling of resentment towards the British, Mountbattens included, begins to emerge. The only two people who seem immune to this feeling are Aalia and Jeet, who are portrayed as firmly trusting the Mountbattens. Jeet's admiration for Mountbatten was declared at the beginning of the film, when he praised him for having freed Burma and his upcoming task to free India. Even Jeet does not see the anomaly of "liberating" a country that you 
had conquered in the first place. Incidentally, it is worth noticing that throughout the film Indian independence is described as a something granted by the British, not obtained by the Indians after decades of struggle: despite the references to political marches and to independence supporters being jailed, independence is still presented mainly in terms of the British granting it, except made for lady Mountbatten's comment that Gandhi "had brought the British Empire to his knees". Describing independence as something that is given rather than taken is an interesting choice because, it resonates with the cultural strategy of colonialism which, as Fanon noted, "wants everything to come from it" (1965, 63), meaning, in this case, that even independence is a gift offered by the magnanimous coloniser as part of his civilizing mission. This perspective is certainly in line with the Churchill's quote that opens the film, "history is written by the victors", but the film remains ambivalent here. It would certainly also be plausible that Indian civil servants would have adopted this perspective and bought into the myth of England just as colonial culture would have wanted, as Macaulay (1835) eloquently explained (see also Lammings, 1960).

Jeet's faith in the viceroy remains strong until Partition kills his romantic dream of marrying Aalia, thus making it a very personal affair rather than a political one. His anger at Mountbatten, at the end of the film, is addressed at the person who has betrayed him - although lady Mountbatten stresses that "this tragedy was not of his making" rather than at the political system he represents, thus somehow weakening the potential to raise questions about the imperial system in itself.

\section{Partition through a diasporic lens}

After having considered the ways in which colonial relations are portrayed in the film, the task is now to understand what makes the film British Asian. From the point of view of style and concept Viceroy's House, being fashioned on the model of English 
heritage costume dramas, undoubtedly provides a British structure to the narrative. The narration of the events through a personalised love story also resonates with many Indian and Pakistani films on Partition, which for years have focused on the impact of Partition on ordinary people rather than engaging directly with its violence (Viswanath and Malik, 2009, 65). Moreover, Viswanath and Malik note that "the recurrent themes in most postPartition cinema in both India and Pakistan of films made after 1947 are separation within a single family, or between lovers" (64), just like Jeet and Aalia. Looking at the film in this perspective, one can see why Chadha calls it "British Asian".

But by describing Viceroy's House as her own “British Asian” take on Partition, Chadha also raises the issue of the relationship between the diaspora and the British empire. In doing so, she calls into question ideas of community and nation, which, at a time of resurgent imperial nostalgia ${ }^{3}$, are central to current debates on national identity in Britain. In her notable work on cinema and Partition, Ira Bhaskar observed how "cinema not only refracts history through the prism of representation, it also forms a collective memory of momentous events and mobilizes memory for an imagining of the community - both national and local" (2005, viii). Portraying Partition does indeed offer the opportunity to mobilise memory for the imagining of the British Asian community, especially because it allows to raise questions about the empire and its legacy, and to offer a counter-narrative to uncritical representations of the empire. Yet, tackling Partition is particularly arduous because "the corporal, material and psychic losses, the widespread sense of betrayal, the overwhelming dislocations - in short, the deep lacerations inflicted on one's sense of self and community - bring up intense and consuming passions" (Sarkar, 2009, 9), as seen in the debate triggered by the film. The challenge is rendered even more difficult by the fact that, if we accept Gilroy's (2004) and Mishra's (2002) suggestions, neither the empire, nor Partition, have been mourned 
yet, hence the violence which is embedded in both is yet to be confronted, by Britain as well as by its former colonies.

In an interview published upon the release of the film Chadha reflected on her take on Partition and its inherent British Asian character in these terms:

By using the upstairs, downstairs formula I was able to access both sides of me as a British Asian -that's an important point of view that we don't often see on the screen. I was able to look at it from different points of view and for me the challenge was to humanise all the characters rather than villainise say, the British (Hawes and Curtis, 2017).

In this light it appears that a British Asian perspective would encompass both the "British" and the "Asian" point of view. Viceroy's House certainly put the spotlight on the impact of Partition on both the British rulers and the Indian subjects. It also shows how people belonging to both groups positioned themselves differently regarding Partition, a very important reminder that, the "British" and the "Indian" points of view do not represent two monolithic, and necessarily juxtaposed, sets of perspectives. And yet, the film is largely dominated by the struggle of Mountbatten, a principled ruler who only wants the best for his country. The problem is not that the viceroy should have been, to use Chadha's words, "villainised", it is the distinction that the film operates between the economic and the cultural aspects of imperialism, the second one strongly advocated by Mountbatten who is portrayed as unaware of the fact that the "civilising" mission was a mere excuse for exploitation, looting, slavery and violence. This way, the film feeds into the very English "fantasy that the British Empire represented something 'noble' or 'great' about Britain; that it was, in spite of all its flaws and meanness and bigotries, fundamentally glamorous" (Rushdie [1984] 1992, 101).

There is no doubt that Viceroy's House holds the British empire accountable for Partition. Following Sarkar, what is narrated in the film is:

An instance of 'colonial' partition, when a departing colonial power seizes the opportunity afforded by competing indigenous nationalisms to produce political and 
social chaos, to suggest - as a way of legitimizing its own colonial project, now largely denuded - that the colonized are not capable of self-rule $(2009,16)$.

But notwithstanding the several remarks that challenge the imperial narrative on colonialism, especially in the "downstairs" area of the house, the film does not follow up on any of the cracks and fissures that emerge, and which have the potential to subvert the colonial discourse. Therefore, even though the film clearly holds the British responsible for Partition, it does not explore for example the roots of communal animosity, which, as Nehru remarks, are grounded in colonial policies.

By putting the spotlight on both the upstairs and downstairs parts of the house, Gurinder Chadha said she was able to look at Partition from different points of view and to "humanise" all characters. This is perhaps the key to understand her British Asian point of view: as mentioned in the introduction, the aim of the film is to provide a "fair" representation of all actors involved and "to offer a message of reconciliation" (Viceroy's House Press Kit, 2017). By emphasising the personal struggles of the actors involved, the film places all parties involved on a (forced) equal level that displaces the political dimension of Partition to highlight how everybody was in fact affected by it. And yet, by so doing the film unwittingly reproduces an image of colonial India according to which the colonisers were not so bad after all. This way the film, to borrow Ponzanesi's words, "while addressing the undercurrent of inequalities", does not engage with them, leaving them "unchallenged and untransformed" (2012, 177). Viceroy's House might speak to everyone, but not everyone was affected in the same way.

\section{Conclusions}

In her work on postcolonial cinema adaptations (2012), Ponzanesi defines Gurinder Chadha "a South Asian diasporic filmmaker who proudly appropriates the many legacies her postcolonial condition offers her" (176). Indeed, her features films, from 
Bhaji on the Beach (1993), to Bend it Like Beckham (2002) and even It's a Wonderful Afterlife (2010) offer a complex portrait of diasporic life in Britain, one which, through humour, contributes to "destabilize essentialist notions of identity, including those identities associated with dominant and cultural nationalism” (Desai, 2004, 65).

Upon its release, Viceroy's House triggered a heated public debate on British Asian identity. Ahmed's reply to Bhutto's criticism of the film in particular emphasised the complex layers that make up the "British Asian" label - for example multiple loyalties and shared memories and experiences with different groups, both in the subcontinent and Britain. At the same time, she also raised the issue of the expectations laid on postcolonial filmmakers as producers of a kind of cinema that turns its gaze back upon "imperial ways of knowing" (Ponzanesi and Waller, 2012, 9) - hence her remark that Chadha "was going to make it [the film] her own way" (Ahmed, 2017).

Yet, even if we accept Ahmed's argument, and Chadha's stated aim to send a message of reconciliation, it is impossible to discard the fact that the film is dominated by Mountbatten and his paternalistic approach to colonial India. This way the film ends up replicating the same sort of fantasy of the empire that, according to Higson, permeates certain heritage films such as A Passage to India, or Jewel in the Crown $(2006,104)$. Just like these films, Viceroy's House conveys a feeling of nostalgia for the past that is "both a narrative of loss, charting an imaginary historical trajectory from stability to instability - in this case Partition - and at the same time a narrative of recovery, projecting the subject back into a comfortably closed past" (Higson 2006, 104). This is in stark contrast with Shashi Tharoor's recent description of colonialism in India, one characterised by "practices of loot, expropriation, and outright theft, enforced by the ruthless wielding of brute power, conducted in a spirit of deep racism and amoral cynicism, and justified by a staggering level of hypocrisy and cant" (2017). 
Viceroy's House has the merit of bringing to the forefront an important part of history that runs the risk of being forgotten ${ }^{4}$, and yet, its preoccupation to provide a humanised portrayals of all character hinders the film's potential to subvert the ideology that underpins heritage cinema. Chadha explicitly said that she did not want to make a “purely political film” (Viceroy's House Press Kit, 2017), but a film on Partition (one of the few around) has the political responsibility not to nurture romanticised versions of the empire, especially at a moment in which postcolonial nostalgia is so strong that, according to data collected in $2014,49 \%$ of the British people still believe that former colonies are better off "for having been part of the empire" (Dahlgreen, 2014).

\section{Acknowledgements}

An early draft of this article was presented at The Global Indian Diaspora Conference in September 2019. The author wishes to thank participants for their precious feedback.

\section{Declaration of Interest}

No potential conflicts of interests in the research, authorship and/or publication of this article

\section{Works Cited}

Ahmed, Sufiya. 2017. "The Attack on Chadha Was an Attack on All Us Brit Asians". Huffington Post, March 6. Accessed 20 September 2019. http://www.huffingtonpost.co.uk/sufiya-ahmed/the-attack-on-gurinderch b 15166450.html

Andrews, Kehinde. 2017. "Colonial nostalgia is back in fashion, blinding us all to the horrors of empire". The Guardian, August 24. Accessed 15 October 2019. https://www.theguardian.com/commentisfree/2016/aug/24/colonial-nostalgiahorrors-of-empire-britain-olympic?CMP $=$ twt_gu

Appadurai, Arjun. 1996. Modernity at Large: The Cultural Dimension of Globalization. Minneapolis: University of Minnesota Press.

Baena, Rosalia and Christa Byker. 2015. "Dialects of nostalgia: Downton Abbey and English identity". National Identities, 17(3): 259-269. doi: 10.1080/14608944.2014.942262

Bhaskar, Ira. 2005. Persistence of Memory: Historical trauma and Imagining the Community in Indian Cinema. PhD dissertation. New York University 
Beaumont, Paul. 2017. "Brexit, Retrotopia and the perils of post-colonial delusions". Global Affairs 3(4-5). 379-390, doi: 10.1080/23340460.2018.1478674

Bhutto, Fatima. 2017. "Fatima Bhutto on Indian partition film Viceroy's House: 'I watched this servile pantomime and wept". The Guardian , March 3. Accessed 18 August 2017. https://www.theguardian.com/film/2017/mar/03/fatima-bhuttoviceroys-house-watched-servile-pantomime-and-wept

Brah, Avtar. 1996. Cartographies of diaspora. Contesting identities. London: Routledge.

Butalia, Urvashi. 1998. The Other Side of Silence: Voices from the Partition of India. New Delhi: Penguin Books.

Butalia, Urvashi. 2005. Women and Partition: A Reader. New Delhi: Zubaan Books.

Byrne, Katherine. 2014. "Adapting heritage: Class and conservatism in Downton Abbey". Rethinking History 18(3), 311-327. doi: 10.1080/13642529.2013.811811

Chadha, Gurinder. 2016. "Gurinder Chadha on Viceroy's House: Why I had to make a film about Partition". The Guardian. April 16. Accessed 18 August 2017. https:/www.theguardian.com/world/2016/apr/16/gurinder-chadha-on-viceroyshouse-why-i-had-to-make-a-film-about-partition

Chadha, Gurinder. 2017a. "History is written by the victors: The inspiration behind Viceroy's House". BBC Blog, $1^{\text {st }}$ March 2017. Accessed 16 September 2019. https://www.bbc.co.uk/blogs/aboutthebbc/entries/2db29f5a-d95d-45b9-ad69f0c0fc327f1b

Chadha, Gurinder. 2017b. "Gurinder Chadha: My film has been wilfully misrepresented as anti-Muslim". The Guardian, 3 ${ }^{\text {rd }}$ March 2017. Accessed 18 August 2017. https://www.theguardian.com/film/filmblog/2017/mar/03/gurinder-chadhadefends-viceroys-house-film-fatima-bhutto

Dahlgreen, Will. 2014. "The British empire is something to be proud of". Lifestyle, Politics and Current Affairs. July 26. Accessed 10 September 2019. https://yougov.co.uk/topics/politics/articles-reports/2014/07/26/britain-proud-itsempire

Darlymple, William. 2015. "The Great Divide, The violent legacy of Indian Partition". The New Yorker. June 29. Accessed 18 August 2017. http://www.newyorker.com/magazine/2015/06/29/the-great-divide-booksdalrymple

Das, Veena and Ashis Nandy. 1985. "Silence, Victimhood and the Language of Violence". Contributions to Indian Sociology 19(1): 177 - 195.

Dave, Paul. 2006. Visions of England. Oxford: Berg.

Davis, Alexander 2018. India and the Anglosphere: Race, Identity and Hierarchy in International Relations, Abingdon: Routledge.

Desai, Jigna. 2004. Beyond Bollywood: The Cultural Politics of South Asian Diasporic Film. New York and London: Routledge.

Fanon, Frantz. 1965. A Dying Colonialism. New York: Grove Press.

Gardner, Andrew. 2017. "Brexit, boundaries and imperial identities: A comparative view". Journal of Social Archaeology 17(1): 3-26.

Gilroy, Paul. 2004. After Empire: Melancholia or Convivial Culture? London: Routledge.

Hall, Stuart. $1990 . \quad$ "Cultural Identity and Diaspora", in, Identity: Community, Culture, Difference, edited by Jonathan Rutherford. (ed.), Lawrence \& Wishart, London, 222-237.

Hall, Stuart. 1996. "Cultural Identity and Cinematic Representation”. In Black British Cultural Studies: A Reader, edited by Houston A. Baker Jr., Manthia Diawara, and Ruth H. Lindeborg, 210-222. Chicago: University of Chicago Press.

Hall, Stuart. 1999. 'Un-settling 'the heritage', re-imagining the post-nation: Whose heritage?", Third Text, 13:49, 3-13. 
Hawes and Curtis. 2017. Exclusive Interview With Director Gurinder Chadha. $8^{\text {th }}$ March 2017. Accessed 15 August 2019. https:/www.hawesandcurtis.co.uk/blog/features/interview gurinder chadha

Higson, Andrew. 2003. English Heritage, English Cinema: Costume Drama since 1980. Oxford: Oxford University Press.

Higson, Andrew. 2006. "Re Presenting the national past: nostalgia and pastiche in the heritage film". In Fires Were Started: British Cinema and Thatcherism, edited by Lester Friedman, 109 - 129. University of Minnesota Press.

Jeffries, Stuart. 2015. "The Best Exotic Nostalgia Boom: Why Colonial Style is Back". The Guardian, March 19. Accessed 10 September 2019. https:/www.theguardian.com/culture/2015/mar/19/the-best-exotic-nostalgiaboom-why-colonial-style-is-back

Khan, Yasmin. 2017. The Great Partition. The Making of India and Pakistan. Yale University Press.

Kumar, Rashmee. 2016. "Coldplay: only the latest pop stars to misrepresent India as an exotic playground", The Guardian. Accessed 10 September 2019. https://www.theguardian.com/music/2016/feb/01/coldplay-beyonce-hymn-forthe-weekend-cultural-appropriation-india

Lamming, George. 1960: 1992. The Pleasures of Exile. Ann Arbor: University of Michigan Press.

Law, Katie. 2019. "William Darlymple: 'I regret joking about Boris's jokes about the EU now". The Evening Standard, 11 September.

Macaulay, Thomas B. 1835: 1995. "Minute on Indian Education". In The Post-Colonial Studies Reader, edited by Bill Ashcroft, Gareth Griffiths and Helen Tiffin, 42830. London and New York: Routledge.

Mishra, Vijay. 2002. Bollywood Cinema: Temples of Desire. New York: Routledge.

Monk, Claire. 2002. "The British heritage-film debate revisited. In: British Historical Cinema: The History, Heritage and Costume Film, edited by Claire Monk and Amy Sargeant, 176-198. London and New York: Routledge.

Nandy, Ashis. 1999. "The invisible holocaust and the journey as an exodus: The poisoned village and the stranger city". Postcolonial Studies: Culture, Politics, Economy 2(3): 305-329

Nayar, Pramod K. 2012. Colonial Voices: The Discourses of Empire. Malden, MA: Wiley Blackwell.

Pandey, Gyanendra. 2001. Remembering Partition. Cambridge: Cambridge University Press.

Ponzanesi, Sandra. 2012. "Postcolonial Adaptations". In Postcolonial Cinema Studies, edited by Sandra Ponzanesi and Marguerite Waller. Abingdon and New York: Routledge.

Ponzanesi, Sandra, and Waller, Marguerite. 2012. Postcolonial Cinema Studies. Abingdon and New York: Routledge.

Rushdie, Salman. [1984] 1992. "Outside the Whale", in Imaginary Homelands, Essays and Criticism 1981 - 91, London: Granta Books, 87 -101.

Sarkar, Bhaskar. 2009. Mourning the Nation: Indian Cinema in the Wake of Partition. Durham, NC: Duke University Press.

Sengupta, Debjani. 2015. The Partition of Bengal: Fragile Borders and New Identities. Cambridge: Cambridge University Press.

Sengupta, Vishnupriya. 2009. "Of "other" histories and identities: partition novels from the Indian subcontinent". Social Semiotics, 19(4): 499-513. doi: $10.1080 / 10350330903361174$ 
Singh, Narendra Sarila. 2006. The Shadow of the Great Game: The Untold Story of Indian Partition. London: Constable.

Tharoor, Shashi. 2017. "India has forgiven Britain for 200 years of imperial enslavement - but we won't forget". International Business Times. March 10. http://www.ibtimes.co.uk/india-has-forgiven-britain-200-years-imperialenslavement-we-wont-forget-1610656

Viswanath, Gita and Malik, Salma. 2009. "Revisiting 1947 through Popular Cinema: A Comparative Study of India and Pakistan". Economic and Political Weekly, 44(36): 61-69.

Viceroy's House Press Kit. 2017. Transmission films, Australia. Accessed 18 August 2017. https://www.transmissionfilms.com.au/films/viceroys-house

Younge, Robert. 2018. "Britain's imperial fantasies have given us Brexit". The Guardian, $\begin{array}{lllll}\text { February } & 3 . & \text { Accessed } & 10 & \text { September }\end{array}$ https://www.theguardian.com/commentisfree/2018/feb/03/imperial-fantasiesbrexit-theresa-may

\section{Films Cited}

A Passage to India, 1984. Directed by David Lean.

Bend it Like Beckham, 2002. Directed by Gurinder Chadha.

Bhaji on the Beach, 1993. Directed by Gurinder Chadha.

Downton Abbey, 2010 - 2015. TV series, ITV network.

Gandhi, 1982. Directed by Richard Attenborough.

Gosford Park, 2001. Directed by Robert Altman.

Heat and Dust, 1983. Directed by James Ivory.

Indian Summers, 2015 - 2016. TV series, Channel 4

It's a Wonderful Afterlife, 2010. Directed by Gurinder Chadha

Jewel in the Crown, 1984. TV series, ITV network.

The Black Prince, 2017. Directed by Kavi Raz.

The Best Exotic Marigold Hotel, 2011. Directed by John Madden.

The Second Best Exotic Marigold Hotel, 2015. Directed by John Madden.

Viceroy's House, 2017. Directed by Gurinder Chadha.

Victoria and Abdul, 2017. Directed by Stephen Frears.

\footnotetext{
${ }^{1}$ Most notably Channel 4's Indian Summers (2015 - 2016), Stephen Frears's Victoria and Abdul (2017), but also films such The Best Exotic Marigold Hotel (John Madden 2011) and its 2016 The Second Best Exotic Marigold Hotel (John Madden 2015). In popular music, see Rashmee Kumar's criticism of Coldplay for reproducing colonial fantasies on the video clip they made for the song Hymn for the Weekend (2016). Kavi Raz's The Black Prince, on the story of the maharajah Duleep Singh, was also released in 2017. While less successful than the aforementioned films, it is notable for providing a counter-narrative to this wave of colonial nostalgia.

${ }^{2}$ The idealised image of the multi-religious village complies with Nandy's observation that, after Partition, "resorting to an idyllic past was a way to relocate people's journey through violence in a universe of memory that is less hate-filled, less buttered by rage and dreams of revenge" $(1999,323)$.

${ }^{3}$ A 2014 poll conducted by YouGov revealed that 59\% of the British public were still proud of the British Empire, with only $19 \%$ claiming to feel ashamed of it. Moreover, the same poll revealed that a third of the British population would have liked Britain to still have an Empire (34\%), while only under half of it declaring to not wanting it (Dahlgreen 2014)
} 
${ }^{4}$ In Britain in particular, where it is not part of the British national curriculum (Elahi 2017) 